\title{
Biotech in China 2021, at the beginning of the 14th five-year period ("145")
}

\author{
Rolf D. Schmid ${ }^{1}$ (D) $\cdot$ Xin Xiong ${ }^{2}$
}

Received: 21 February 2021 / Revised: 13 April 2021 / Accepted: 21 April 2021 / Published online: 3 May 2021

(C) The Author(s), under exclusive licence to Springer-Verlag GmbH Germany, part of Springer Nature 2021

\begin{abstract}
As China assumes a more and more dominant role in global science, this mini-review attempts to provide a bird's eye view on how the bio-digital revolution impacts China's biosciences and bioindustry. Triggered by top-down political programs and the buildup of an impressive infrastructure in science, information technology, and education, China's biomedical and MedTech industries prosper. Plant and animal breeding programs transform agriculture and food supply as much as the Internet of things, and synthetic biology offers new opportunities for the manufacturing of specialty chemicals within the Chinese version of a "bioeconomy." It is already becoming apparent that the new five-year period "145" (2021-2025) will further emphasize emission control, bioenvironmental protection, and more supply of biomass-derived energy. This review identifies key drivers in China's government, industry, and academia behind these developments and details many access points for deeper studies.
\end{abstract}

\section{Key points}

- Biotechnology in China

- Biomedical technology

- New five-year period

Keywords China's industrial biotechnology $\cdot$ Synthetic biology $\cdot$ Medical biotechnology $\cdot$ Plant breeding $\cdot$ Fermented food $\cdot$ Emission control

\section{Introduction and megatrends}

On December 31, 2020, China's 13th five-year period ("135") has ended. Achievements during this period and plans for the 14th five-year period "145" (2021-2025) are gradually being published. Among many other advances, China has now become a major player in global science and technology. As of the end of 2019, the nation spent 2.2 trillion CN¥ (Chinese yuan)

An extended version of this review is in print and due to appear as a book in June 2021; see Rolf Schmid and Xin Xiong, Biotech in China - innovation, politics and economics, ISBN 9789814877534. Updates on current biotech innovations in China can be found under the website of both authors under www.window-to-china.de.

Rolf D. Schmid

rolf.d.schmid@bio4business.eu

Bio4Business, Jagdweg 3, D-70569 Stuttgart, Germany

2 NMI Natural and Medical Sciences Institute, University of Tuebingen, Markwiesenstr. 55, D-72770 Reutlingen, Germany equivalent to 280 billion $€$ (CNBS-Chinese National Bureau of Statistics $2020 \mathrm{a}, \mathrm{b}$ ), or $2.2 \%$ of its gross domestic product (GDP), on science and technology (S\&T), the second largest expenditures after the USA. About 100 million Chinese work in S\&T-related fields, $50 \%$ of them hold an academic degree, and more than 40 million youngsters leaving school each year continue high school training, half of them in science, agronomy, or medicine. Out of nearly 6.6 million young Chinese who studied abroad since 1978, mostly in North America, Europe, or Japan, over 4.23 million or $86 \%$ have chosen to return home and now hold positions in academia or industry (MOE-Ministry of Education of China (2020)-1 2019, MOE- Ministry of Education of China (2020)-2 2019). As a result, the output of scientific papers from China, according to the Nature Index, is now at about $20 \%$ of the world, and $25 \%$ in bioscience and medicine (Nature Index 2020). By impact, publications from institutes of the Chinese Academy of Sciences and from some Chinese universities have climbed to the top 50 in the world. In 2019, China accounted for some $22 \%$ of all international patent applications, more than the USA (Gurry 2020). 
The foundation for these developments lies in the firm belief of Chinese leadership that S\&T is indispensable to modernize a populous and large nation that 50 years ago was still widely underdeveloped. The results are impressive. In 2020, China has built a $155,000-\mathrm{km}$ highway net (Chen 2020) for its 365 million cars (Liu 2020), 39,000 km of high-speed railway, and, even more important, the satellite network Beidou ("North Star") based on some 30 communication satellites which network mainland China and start to extend to other parts of the world. As the global number 2 in fast computers, and with one of the best $4 \mathrm{G} / 5 \mathrm{G}$ networks in the world, modern information technology (IT) applications such as education, the Internet of things (IoT), or cloud-based services strive and provide an excellent base for the use of "big data" in biotech as well. However, many tasks remain: the fight against rural exodus and poverty, enhanced productivity in agriculture, improvements of the health system throughout a very unevenly inhabited nation, and urgent changes in energy supply mostly coal - which not only are at the heart of China's severe air pollution but also engage a sizable number of its workers.

\section{Regional considerations}

China ranks number 4 among the world's largest nations, with roughly the size of the USA or Canada. Its 4 municipalities (Beijing, Tianjin, Shanghai, and Chongqing), 5 autonomous administrative regions, and 23 provinces represent quite different levels of population and economic wealth. China's master plan for a more even economic development of the country calls for 4 major hubs, which radiate into the neighboring provinces (Fig. 1). In 2020, these 4 hubs hosted $53 \%$ of the Chinese population and generated $63 \%$ of China's GDP (CNBS 2020-2023). Most of China's biomedical and biotechnology research and development (R\&D) is located there, in 169 national and over 1000 provincial high-tech zones which host the majority of S\&T personnel in industry. By the end of 2019, the national High-Tech Zone achieved a GDP of 12 trillion $\mathrm{CN} ¥$, equivalent to 1.55 trillion $€$, accounting for $12.3 \%$ of the national GDP (Wen 2020; MOST 2019).

As to academic R\&D, most high-level universities among the nation's 2668 universities and colleges are located along the Pacific Rim, from Dalian to Hong Kong. Some of these universities have now started to establish teaching and research affiliations inland, such as the Jiaotong Universities in Xi' an and Chengdu. The other major organization in R\&D, the Chinese Academy of Sciences (CAS), has established its 12 branch affiliations across the whole country, including 104 research institutions, some 1000 stations and sites, and over 60,000 employees (CAS 2020). The CAS and its 2 elite universities, the University of Science and Technology of China (USTC) in Hebei and the University of Chinese Academy of Sciences (UCAS) in Beijing, rank on positions 1, 11, and 13 of the global Nature Index 2020.

\section{Health-related developments}

In 2018, the average life expectancy at birth in China was 77.9 years for women and 75.0 years for men (World Health Organization (WHO) 2020). About 180 million Chinese or $13 \%$ of the population were older than 65 years (CER 2020). It is estimated that this number will rise to 329 million or $23.6 \%$ by 2050 . As a consequence of an aging society, the 5 leading causes of death in 2017 were stroke, ischemic heart disease, lung cancer, chronic obstructive pulmonary diseases, and liver cancer. Lifestyle diseases are also on the rise. Thus, China counted 116 million diabetics (Statista 2019) in 2019 and over 2.8 million deaths from cancer in 2018 (Cao et al. 2020). The public healthcare system is centrally organized with about 33,000 hospitals in the cities, community health centers in the regions, and about 3 million registered doctors, supported by over a million "migrant doctors" and health workers in the countryside, increasingly connected via a 4G/5G network and "Internet hospitals." Public healthcare insurance now covers 1.35 billion or $96.4 \%$ of all Chinese, at least to some extent.

\section{The industry}

At the end of 2018, China counted 4441 pharmaceutical manufacturers; however, over $70 \%$ of these companies had annual sales of less than 100 million CN¥, equivalent to 13 million $€$. Chinese companies lead the world market as suppliers of active pharmaceutical ingredients (API), vaccines, and antibiotics. In 2018, the size of the pharmaceutical market was about 2.1 trillion CN¥, equivalent to 270 billion $€$. Twelve percent came from biologics, with a share of $39 \%$ for vaccines, $16 \%$ for recombinant insulins, $15 \%$ of blood products (mostly human serum albumen), and only $11 \%$ from therapeutic antibodies (most antibiotics are considered chemical drugs and do not fall into this category). Generally speaking, highly innovative drugs still originate from international companies, and Chinese manufacturers excel in generics and traditional Chinese medicine (TCM). However, innovation is strongly supported by the government through tax breaks, government purchase regulations, and infrastructures such as science parks. Table 1 provides a shortlist of biopharmaceutical companies in China and typical biopharmaceutical products.

\section{Medicinal plants and traditional Chinese medicine}

About $30 \%$ of all drugs sold in China are TCM products, as their use is deeply rooted in Chinese culture and their prescription strongly supported by the government. Thus, primary 


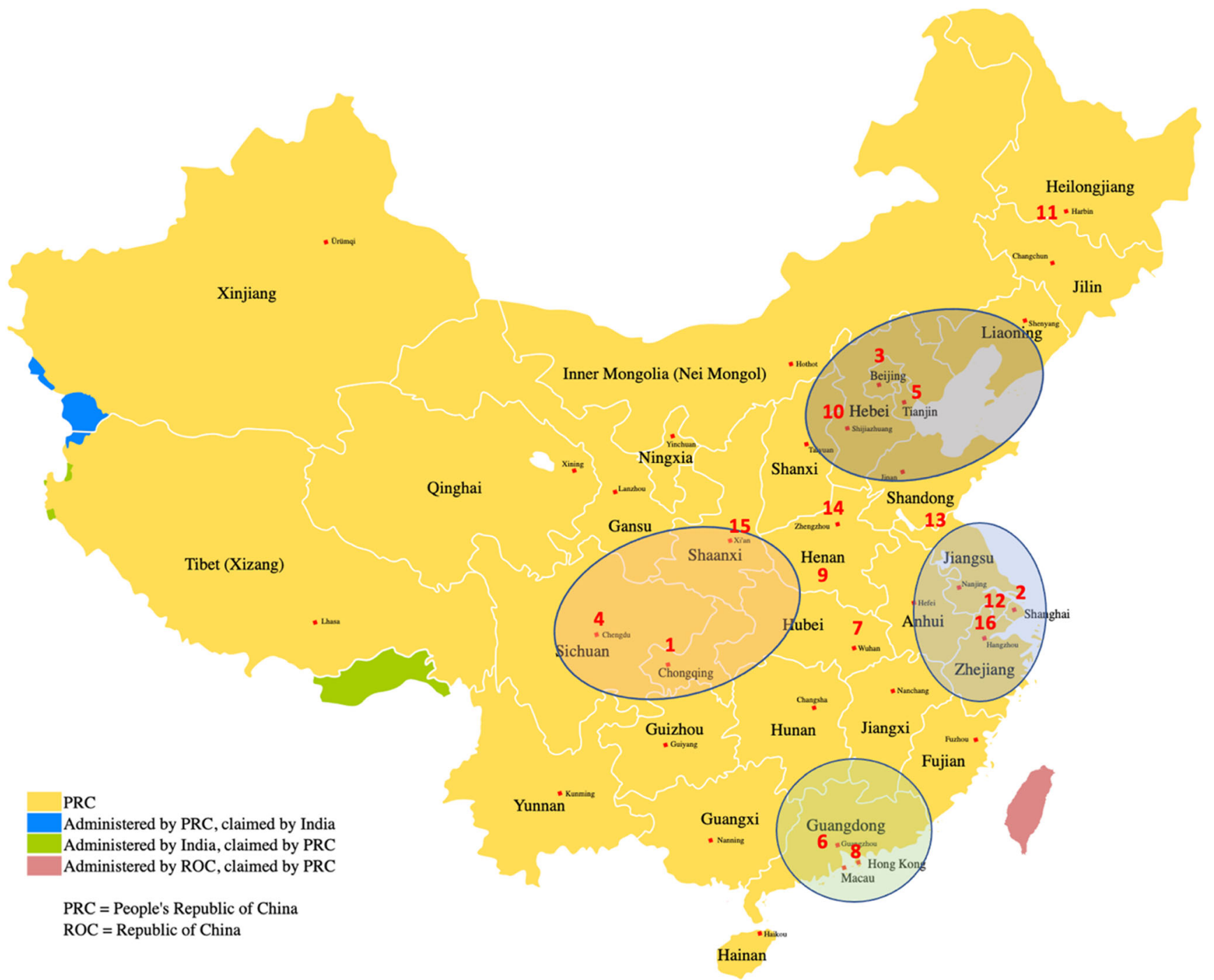

Fig. 1 Map of China and four biobusiness clusters (map from Wikimedia China administrative, ASDFGH). As of 2020, China had 16 megacities with over 10 million inhabitants. These were, ranked by population (number is also position on map), (1) Chongqing, (2) Shanghai, (3) Beijing, (4) Chengdu, (5) Tianjin, (6) Guangzhou, (7) Wuhan, (8) Shenzhen, (9) Nanyang, (10) Shijiazhuang, (11) Harbin, (12) Suzhou, (13) Linyi, (14) Zhengzhou, (15) Xi'an, and (16) Hangzhou. Much of

schools and high schools provide obligatory lectures on TCM for all students. In 2018, 2350 manufacturers of TCM created sales in excess of 900 billion CN¥, equivalent to 117 billion $€$. Registered raw materials for TCM numbered some 12,800, of which over 11,100 were from plants. Among 12,000 documented medicinal plants, nearly 7300 came from Sichuan Province in Central China, dubbed "China's pharmacy." TCM-Related research was recently stimulated by the Nobel Prize for Medicine in 2015 to TU Youyou (Famous Scientist 2018). Her discovery of artemisinine as a malaria drug, in 1972, was based on information from historic textbooks on TCM and modern methods of isolation and characterization of active ingredients.
China's pharmaceutical research and industry is located in 4 biobusiness clusters shown here as bubbles: the northeastern cluster (Liaoning, Hebei, Beijing, Tianjin, and Shandong), the eastern cluster (Jiangsu, Zhejiang and Shanghai), the southern cluster (Guangdong and Hong Kong), and the western cluster (Sichuan, Shaanxi, Hubei and Chongqing). In these 4 clusters lived $53 \%$ of the Chinese population and generated $63 \%$ of China's GDP

\section{The MedTech industry}

By the end of 2018, some 17,000 manufacturers of MedTech products were certified in China. Table 2 provides a shortlist of leading companies and their products. There were 52 listed manufacturers of in vitro diagnostics (IVD), with sales of about 60 billion $\mathrm{CN} ¥$ equivalent to 7.8 billion $€$, of which $80 \%$ were spent for test kits. The rise of a well-educated middle-class population with more disposable income, an aging society, and technological developments such as cloud computing, rapid data transmission, and second-generation sequencing all contribute to a wider use of IVD in hospitals and at home. An international success story is BGI's non-invasive 
Table 1 A shortlist of Chinese pharmaceutical and biopharmaceutical companies

\begin{tabular}{|c|c|c|c|c|c|}
\hline Company name & Type & STN & $\begin{array}{l}\text { Sales } 2019 \\
\text { (million CN¥; million } € \text { ) }\end{array}$ & $\begin{array}{l}\text { R\&D } 2019 \\
\text { (million CN¥; million } € \text { ) }\end{array}$ & Biopharmaceutical products (examples) \\
\hline $\begin{array}{l}\text { Jiangsu Hengrui }^{\mathrm{a}} \\
\text { 恒瑞医药 }\end{array}$ & $\mathrm{P}$ & SHA:600276 & 23,$289 ; 3015$ & $3896 ; 504$ & PD-1 monoclonal antibodies \\
\hline $\begin{array}{l}\text { Shanghai Fosun Pharma }{ }^{\mathrm{b}} \\
\text { 上海复星医药 }\end{array}$ & $\mathrm{P}$ & $\begin{array}{l}\text { SHA: } \\
\quad 600196\end{array}$ & 28,$585 ; 3701$ & $3463 ; 448$ & Rituximab, H1N1 vaccine \\
\hline $\begin{array}{l}\text { Qilu Pharmaceutical } \\
\text { 齐鲁制药 }\end{array}$ & S & - & 25,$100 ; 3250$ & $1600 ; 207$ & Bevacizumab monoclonal antibody \\
\hline $\begin{array}{l}\text { Zhejiang Hisun }^{\mathrm{d}} \\
\text { 海正药业. }\end{array}$ & $\mathrm{P}$ & $\begin{array}{l}\text { SHA: } \\
\quad 600267\end{array}$ & 11,$072 ; 1433$ & $814 ; 105$ & Insulin, adalimumab \\
\hline $\begin{array}{l}\text { Chongqing Zhifei } \\
\text { 重庆智飞生物 }\end{array}$ & $\mathrm{P}$ & SHE:300122 & 10,$600 ; 1327$ & $259 ; 34$ & $\begin{array}{l}\text { Hib vaccine, HPV vaccine, } 23 \text {-valent } \\
\text { pneumococcal polysaccharide } \\
\text { vaccine, etc. }\end{array}$ \\
\hline $\begin{array}{l}\text { Salubris } \\
\text { Pharmaceuticals } \\
\text { Ph信立泰药业 }\end{array}$ & $\mathrm{P}$ & SHE: 002294 & 4,$470 ; 579$ & $763 ; 99$ & Recombinant human parathyroid hormone \\
\hline $\begin{array}{l}\text { Walvax Biotechnology } \\
\text { 云南沃森生物技术 }\end{array}$ & $\mathrm{P}$ & SHE: 300142 & $1121 ; 145$ & $65 ; 8.4$ & $\begin{array}{l}\text { 23-Valent pneumococcal polysaccharide } \\
\text { vaccine, etc. }\end{array}$ \\
\hline $\begin{array}{l}\text { InnoventBio }^{\mathrm{h}} \\
\text { 信达生物 }\end{array}$ & $\mathrm{P}$ & HKG:1801 & $1048 ; 140$ & $1294 ; 168$ & $\begin{array}{l}\text { PD- } 1 \text { monoclonal antibody, } 20 \text { biomedical } \\
\text { drugs in approval procedure or preclinical } \\
\text { studies }\end{array}$ \\
\hline
\end{tabular}

$S$ state-owned company, $P$ private company, $S T N$ stock trading number

${ }^{\mathrm{a}} \mathrm{https}: / /$ www.hrs.com.cn

${ }^{\mathrm{b}} \mathrm{https}: / /$ www.fosunpharma.com

${ }^{\mathrm{c}} \mathrm{http}: / / \mathrm{m}$.qilu-pharma.com

${ }^{\mathrm{d}} \mathrm{http}: / /$ www.hisunpharm.com

${ }^{\mathrm{e}} \mathrm{http}: / /$ www.zhifeishengwu.com

${ }^{\mathrm{f}} \mathrm{http}: / /$ www.walvax.com

${ }^{\mathrm{g}}$ https://www.walvax.com

${ }^{\mathrm{h}} \mathrm{http}: / /$ innoventbio.com/\#/

prenatal diagnosis test for genetic screening, based on fetal DNA collected from maternal blood. BGI's NIFTY test offers screening for Down's syndrome, trisomy 13 and 18, and other genetic effects and is now available not only in China but also in many countries around the world (BGI 2017).

\section{Genome sequencing, gene banks, and personalized medicine}

Among over 200 sequencing companies in China, the two major players are the BGI in Shenzhen and GENEWIZ in Suzhou. A third large center, National Health Medical Big Data Center in Nanjing, is presently under construction. BGI has published a study on the whole genomes of some 141,000 Chinese women, based on their NIFTY tests (BGI 2018), and a "Chinese genome map" was built on the basis of 597 healthy individuals from most areas of China (Du et al. 2019) stimulated by the fact that in Western human genome programs the Chinese population is underrepresented. These efforts are meant to facilitate genetic testing and personalized medicine and include "gene banks" such as the National Gene
Bank in Shenzhen, co-financed by BGI (Fig. 2), and the Biobank in Shanghai's Zhangjiang Business Park.

\section{Cell-based medicine and animal models for disease and brain research}

Supported by a 2015 master plan of the MOST, cell and stem cell technologies are important areas of R\&D in China $(\mathrm{Hu}$ et al. 2018). Major cell depositories are the Global Cord Blood Cooperation (GCBC), which stores cord blood of babies as a resource for stem cells later in their life, and Beike Biotechnology located in Taizhou's China Medical City which is a key player in the National Stem Cell Industrialization Programme.

Other aspects of cell technology are organ replacement and xenotransplantation. According to the China Medical Association, 4733 human livers, 10,793 kidneys, 446 hearts, and 299 lungs were transplanted in 2017 in 178 licensed hospitals (Shi et al. 2020). Chinese research on xenotransplantation of porcine cells or whole pancreas is also high. Cells and organs are provided by transgenic pigs producing human 
Table 2 A shortlist of Chinese biomedical and IVD companies

\begin{tabular}{|c|c|c|c|c|}
\hline Company name & Type & STN & $\begin{array}{l}\text { Sales } 2019 \\
\text { (million CN¥; million } € \text { ) }\end{array}$ & Major products \\
\hline $\begin{array}{l}\text { Mindray Medical Devices } \\
\text { 迈瑞医疗 }\end{array}$ & $\mathrm{P}$ & SHE: 300760 & 16,$500 ; 2136$ & Ultrasound devices, patient monitoring, IVD \\
\hline $\begin{array}{l}\text { Dian Diagnostics Group } \\
\text { 迪安诊断 }\end{array}$ & $\mathrm{P}$ & SHE: 300244 & $8500 ; 1100$ & Diagnostics, molecular diagnostics \\
\hline $\begin{array}{l}\text { LePu Medical technology } \\
\text { 乐普医疗 }\end{array}$ & $\mathrm{S}+\mathrm{P}$ & SHE: 300003 & $7800 ; 1010$ & Cardiovascular implants, stents \\
\hline $\begin{array}{l}\text { Yuwell Medical } \\
\text { 鱼跃医疗 }\end{array}$ & $\mathrm{P}$ & SHE: 002223 & $4600 ; 596$ & Oxygen concentrator, breath care, blood pressure monitoring \\
\hline $\begin{array}{l}\text { Blue Sail Medical }^{\mathrm{e}} \\
\text { 蓝帆医疗 }\end{array}$ & $\mathrm{P}$ & SHE: 002382 & $3500 ; 453$ & Health care products and stents \\
\hline $\begin{array}{l}\text { Medical System Biotechnology }{ }^{\mathrm{f}} \\
\text { 美康生物 }\end{array}$ & $\mathrm{P}$ & SHE: 300439 & $3300 ; 427$ & Biological IVD kits \\
\hline $\begin{array}{l}\text { Maccura Biotechnology } \\
\text { 迈克生物 }\end{array}$ & $\mathrm{P}$ & SHE: 300463 & $3200 ; 414$ & IVD, PCR \\
\hline $\begin{array}{l}\text { BGI Group } \\
\text { 华大基因 }\end{array}$ & $\mathrm{P}$ & SHE: 300676 & $2800 ; 363$ & IVD, e.g., for neonatal testing, tumor diagnostics \\
\hline $\begin{array}{l}\text { Shanghai Kehua Bioengineering }{ }^{\mathrm{i}} \\
\text { 科华生物 }\end{array}$ & $\mathrm{S}$ & SHE: 002022 & $2400 ; 311$ & IVD \\
\hline $\begin{array}{l}\text { Shanghai Tofflon }{ }^{\mathrm{a}} \\
\text { 东富龙 }\end{array}$ & $\mathrm{S}$ & SHE: 300171 & $2300 ; 298$ & Injectables and packaging \\
\hline
\end{tabular}

$S$ state-owned company, $P$ private company, $S T N$ stock trading number

${ }^{\mathrm{a}} \mathrm{http}: / / \mathrm{www} \cdot \mathrm{mindray} . \mathrm{com}$

${ }^{\mathrm{b}} \mathrm{http}: / /$ www.dazd.cn

${ }^{\mathrm{c}} \mathrm{http}: / /$ www.lepumedical.com

${ }^{\mathrm{d}} \mathrm{http}: / /$ www.yuwell.com

${ }^{\mathrm{e}} \mathrm{http}: / /$ www.bluesail.cn

${ }_{\mathrm{f}}^{\mathrm{f}} \mathrm{ttp}: / / \mathrm{www} \cdot \mathrm{nb}$-medicalsystem.com

${ }^{\mathrm{g}} \mathrm{https} / / /$ www.maccura.com

${ }^{\mathrm{h}} \mathrm{https}: / /$ www.genomics.cn

${ }^{\mathrm{i}} \mathrm{https}: / / \mathrm{www} \cdot \mathrm{skhb} \cdot \mathrm{com} / \mathrm{cn} /$

${ }^{\mathrm{j}} \mathrm{http}: / /$ www.tofflon.com

insulin and reared in a pathogen-free environment (Wang et al. 2019). Pigs are also being developed as animal models of human diseases ( Wu 2018), and isogenic cats and dogs are bred from mature parental oocytes by somatic cell nuclear transfer followed by embryo transfer in a commercial setting (Sinogene 2020). The National Resource Center for Mutant Mice at Nanjing University hosts over 3500 strains (NRCMM 2020). China's vantage point, however, are Macaque mon- keys for which a long-read genome map is available and which are bred in over 24 facilities throughout China (Cyranoski 2018). Within the China Brain Project, started in 2017, a group of institutes such as Peking and Tsinghua University, the CAS Institute of Neurosciences in Shanghai, and the Academy of Military Medical Sciences will use this resource and focus on brain science and brain-like intelligence technology (Shi et al. 2019).

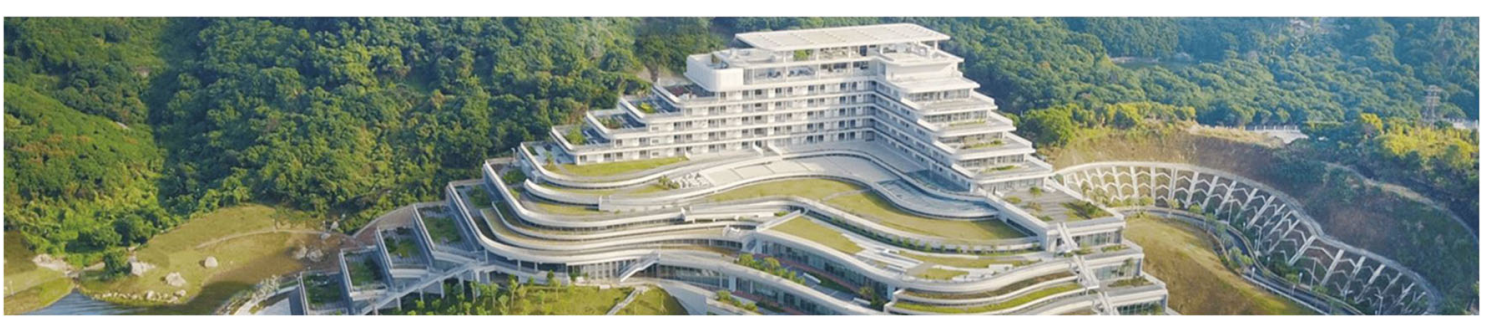

Fig. 2 National Gene Bank in Shenzhen. Photo credits: CNGB website 


\section{Telemedicine and Internet hospitals}

Medical digital records in Chinese hospitals add up to some 800 million people from 8 billion patient appointments every year. Internet-based medical services have begun to curb unnecessary visits to doctors, and 38,000 hospitals can already be reached via the Internet for patient inquiries or consultations among doctors. The Internet, augmented reality, and fast data communication open new opportunities for sensor-based telemedicine based on portable instruments, for evidencebased diagnoses using image analysis, and for a robot-based support for initial patient interviews and preliminary therapy, including the use of TCM (Sun et al. 2020).

\section{COVID-19 pandemic}

Following the SARS-COV-1 epidemic in 2002, a much more aggressive coronavirus, SARS-COV-19, originated in Wuhan in late 2019. As this review is written, there are over 150 million confirmed cases and over 2 million victims on all continents. China counted some 80,000 infected people, of which some 5000 died. However, based on strict social distancing and the obligatory use of a "personal health code" on everybody's cellular phone, China now seems to be under control of this outbreak. PCR-Based assays are done at levels of several 100,000 per day per provincial center. In addition, several vaccines were developed in record time. The leading supplier has successfully passed clinical studies of phase III in 12 countries and is now offering its vaccine, based on an attenuated COVID-19 strain. Fourteen more vaccines, including some based on mRNA, are under phase II or III studies. The first vaccine based on inactivated corona viruses, developed by the Beijing Institute of Biological products (SinoPharm Biotechnology), has gotten conditional approval for emergency use by National Medical Products Administration (NMPA) on Dec. 31, 2020 (People's Daily 2020), and the government claims that over 22 million people have been vaccinated as of January 26, 2021 (Yi 2021). Production of this vaccine is said to rise to over 2 billion doses in 2021.

\section{Industrial biotechnology}

Over the past decades, China has become a leading global producer of fermentation products such as ethanol, amino acids, citric, malic and lactic acid, vitamins, industrial enzymes, and biopolymers. Apart from servicing large national markets, a sizable amount of these products is exported, and manufacturers, which often number in the dozens, suffer from overcapacities. Usually, only a few companies control these markets, and they apply R\&D strategies not only to improve strains but also to reduce raw material cost and the environmental load of their processes.

\section{Amino acids}

Chinese companies lead the world in the production of bulk amino acids such as L-glutamate, L-lysine, L-threonine, and Ltryptophane. Table 3 provides a survey on the leading companies and their products.

\section{Hydroxy acids}

The estimated production of citric acid in China in 2019 was 1.37 million t. Among about 100 manufacturers, the top 4, Ensign World, Luxin Jinhe, Tiantian Citric Acid, and Cofco, account for over $90 \%$ of production. L-Malic acid is manufactured by Changmao Biochemical Engineering at an annual scale of about $5000 \mathrm{t}$ through the enzymatic addition of water to fumaric acid using immobilized cells of Escherichia coli (Tanabe process).

\section{Vitamin C}

China has a long tradition in manufacturing vitamin $\mathrm{C}$ (ascorbic acid). Originally following the chemo-fermentative procedure developed by Tadeus Reichstein at Hoffmann-La Roche, researchers at the CAS Institute of Microbiology later changed to a two-step fermentation where glucose is first transformed into 2-keto-L-gulonic acid by microbial cells followed by chemical transformation, which was transferred to Hoffmann-La Roche in 1985, becoming the first large technology export from the People's Republic of China (Yang and Xu 2016). In 2018, China produced 60,000 t of vitamin C, of which $70 \%$ was exported.

\section{Ethanol}

Out of 108 billion L of fuel ethanol produced globally in 2018, China produced 2.89 million $t$ or about $4 \%$. Current domestic gasoline consumption stands at about 130 million t. As China targets 10\% ethanol addition to gasoline by 2020 (E10), the demand for fuel ethanol would be about 13 million $t$, more than fourfold the amount produced (Zhang 2019). As of 2006, production by the four leading companies, shown in Table 4, had reached 1.24 million $t$, mostly from aged grain as a carbon source. Then, corn and wheat prices rose sharply and a discussion on their use for "eat or drive" developed. As a consequence, the National Development and Reform Commission (NDRC) stopped the approval of using corn and wheat and encouraged companies to produce fuel ethanol from non-food resources such as cassava, sweet potato, sweet sorghum, straw, or woody residues. Subsidies for projects of this kind were up to $1200 \mathrm{CN} ¥$ equivalent to $155 € /$ t of ethanol. 
Table 3 Leading Chinese manufacturers of amino acids and hydroxy acids

\begin{tabular}{|c|c|c|c|c|}
\hline Product & Company name, location & Type & STN & Estimated production (2019) \\
\hline \multirow[t]{4}{*}{ Amino acids } & Fufeng ${ }^{\mathrm{a}}$, Shandong & $\mathrm{P}$ & HK: 0546 & 1.1 million $\mathrm{t}$ glu, starch sweetener $650,000 \mathrm{t}, 176,000 \mathrm{t}$ thr, 200,000 Lys \\
\hline & Meihua $^{\mathrm{b}}$, Hebei & $\mathrm{P}$ & SHA: 600873 & 758,799 t glu, $9399 \mathrm{t}$ medical aa, 1,795,794 t animal feed aa. \\
\hline & Eppen $^{\mathrm{c}}$, Ningxia & $\mathrm{P}$ & - & $300,000 \mathrm{t}, 660,000 \mathrm{t}$ lys $(2018)$ \\
\hline & Global Biochem Technology Group ${ }^{\mathrm{d}}$ & $\mathrm{P}$ & HK: 00809 & $186,000 \mathrm{t}$ lys, thr, corn sweetener $299,000 \mathrm{t}$ \\
\hline \multirow[t]{4}{*}{ Citric acid } & Ensign World ${ }^{\mathrm{e}}$ & $\mathrm{P}$ & - & $600,000 \mathrm{t}(2018)$ \\
\hline & Luxin Jinhe ${ }^{\mathrm{f}}$ & $\mathrm{P}$ & - & $360,000 \mathrm{t}(2018)$ \\
\hline & Tiantian Citric Acid ${ }^{\mathrm{g}}$ & $\mathrm{P}$ & - & $300,000 \mathrm{t}(2018)$ \\
\hline & Cofco $^{\text {h }}$ & $\mathrm{S}$ & SHE: 000930 & $340,000 \mathrm{t}(2018)$ \\
\hline Malic acid & Changmao Biochemical Engineering ${ }^{\mathrm{i}}$ & $\mathrm{P}$ & - & $5000 \mathrm{t}(2018)$ \\
\hline
\end{tabular}

$g l u$ L-glutamic acid or monosodium glutamate, $l y s$ L-lysine, $t h r$ L-threonine, $\operatorname{trp}$ L-tryptophane, $P$ private company, $S$ state-owned company, $S T N$ stock exchange number

${ }^{\mathrm{a}}$ http://www.fufeng-group.com

${ }^{\mathrm{b}} \mathrm{http}: / / \mathrm{www} . \mathrm{meihuagrp.com}$

${ }^{\mathrm{c}}$ http://www.eppen.com.cn

${ }^{\mathrm{d}}$ http://www.globalbiochem.com/html/index.php

${ }^{\mathrm{e}} \mathrm{http}: / /$ www.ensignworld.com

${ }^{\mathrm{f}} \mathrm{http}$ ://www.rzbc.com

${ }^{\mathrm{g}} \mathrm{http}: / / \mathrm{www} . t t c a . c o m . c n$

${ }^{\mathrm{h}}$ http://www.cofco.com/cn/BrandProduct/COFCOBiochemical/

${ }^{\mathrm{i}} \mathrm{http}: / / \mathrm{www} . \mathrm{cmbec} . \mathrm{com} / \mathrm{home} /$ index.asp

Recently, these developments were frozen due to new priorities for mobile energy relating to methanol from coal, electromobility, and, most recently, development of hydrogen-fueled trucks and cars.

Following a new concept of bioethanol production from syngas, proposed in 2012 by LanzaTech, there are presently several steel companies such as Baosteel, Beijing Shougang, and Capital Steel which have built pilot plants exploring this process in practice. Capital Steel operates an effluent-toethanol plant with an annual capacity of $46,000 \mathrm{t}$ of ethanol (LanzaTech 2018).

\section{Industrial enzymes}

The use of technical enzymes in China differs from uses in Western countries: enzymes for starch degradation, for the brewing industry, and for dairies are widely used. The most important, however, are enzymes such as cellulases, laccases, and phytases for animal feed. In 2018, 80,000 t of enzymes were used for this purpose with a value of over 2 billion CN¥ equivalent to 260 million $€$, over $80 \%$ of the total production (CHYXX 2019). Major enzyme producers are listed in Table 5.

\section{Biopolymers}

In 2019, the estimated production of biodegradable polymers such as PLA or PBS was at 520,000 $\mathrm{t}$ and rose to 1 million $\mathrm{t}$ in 2020. Estimates for 2025 are 4-5 million $t$ (Jin 2021). China leads also in the global production of some biopolymers, e.g., xanthan and sodium alginate.

\section{Academic R\&D and technology transfer}

Innovative processes for industry are often initiated by academic institutions which explore new technologies, introduce new methods, and transfer them to industry through licensing, transfer of staff, or the foundation of start-up companies. The development of new industrial processes for the manufacture of a wide range of fine chemicals by fermentation or in plants is presently at a dynamic stage due to novel tools in synthetic biology, metabolic engineering, and robot-assisted highthroughput analysis of candidate production strains ("smart cells"). Dozens of academic groups throughout China have embarked on such technologies, with a focus on new enzymes, new host organisms, or high-yield conversion of natural substrates. IT infrastructure and access to service providers, e.g., for genome sequencing, are excellent in China. 
Table 4 Major bioethanol producers in China (2018)

\begin{tabular}{lccl}
\hline Company & Type & Capacity (t/year) & Carbon source** \\
\hline Henan Tianguan $^{\mathrm{a}}$ & $\mathrm{S}$ & 700,000 & Wheat, corn, manihot \\
Jilin Fuel Ethanol $^{\mathrm{b}}$ & $\mathrm{S}$ & 600,000 & Corn \\
Cofco (Anhui) $^{\mathrm{c}}$ & $\mathrm{S}$ & 400,000 & Corn, manihot \\
Cofco (Zhaodong) & $\mathrm{S}$ & 400,000 & Corn \\
Guangxi Cofco Biomass Energy $^{\text {(Z) }}$ & $\mathrm{S}$ & 200,000 & Manihot \\
\hline
\end{tabular}

Source: https://www.niumoney.com/news/notice_132426.html, http://baogao.chinabaogao.com/ huaxuechangpin/515429515429.html

$S$ state-owned

${ }^{* *}$ Currently $87 \%$ of the raw material source is corn; $11 \%$ is cassava (manihot) or sugar cane, and only $2 \%$ is cellulose, and fed-batch fermentation using Saccharomyces cerevisiae is the standard process. As corn supply is limited, E10 targets may not be reached in 2020

${ }^{a}$ http://www.tianguan.com.cn/english/

${ }^{\mathrm{b}} \mathrm{http}: / / \mathrm{www} . \mathrm{cnpc} \cdot \mathrm{com} \cdot \mathrm{cn} / \mathrm{en} /$

${ }^{\mathrm{b}} \mathrm{http}: / / \mathrm{www} . c 0 f$ cotech.com

Table 7 provides a shortlist of leading universities and institutes in this field and a selection of targets.

Technology transfer to companies is a key element of the "Made-in-China 2025" plan and is supported by a wide range of political and financial measures (Table 6). As shown in Fig. 3, many technology transfer opportunities can be related to biobusiness.

\section{Biotechnology in agriculture}

In 2000, $70 \%$ of China's population still worked in agriculture, and even in $2014,45 \%$ of all Chinese lived in rural areas. They make China the world's largest producer of rice, contributing about $30 \%$ to global production, and of other important crops such as corn, wheat, millet, sorghum, barley, potatoes and sweet potatoes, soybean, rapeseed, and sugarcane. China produced 17.3 million $t$ of peanuts in 2018, being on top in the world. Most of the nuts are used to produce peanut oil, the Chinese cooking equivalent of olive oil in Western countries. Other large crops are tea, tobacco, and cotton. Classical breeding of cultivars has been done for many decades, and a most relevant example was the breeding of hybrid rice through crossbreeding of a wild rice species with a malesterile strain. Starting from the 1970s, such work by Yuan Longpin and colleagues at Hunan Agricultural University led to a high-yield hybrid cultivar which helped farmers nearly quadruple China's rice production compared to 1950. Yuan's team recently has bred an alkaline- and salt-resistant rice variety which apparently provides good harvests on hitherto unfertile soils (Guo 2021). Research on transgenic crops is well established in China, and $90 \%$ of all cotton plants are insectresistant Bt cotton. Transgenic papaya and poplars have also been planted. However, the Ministry of Agriculture, responsible for regulations on the release of environmental crops, so far has generally hesitated to license transgenic crops for food use - a consequence of consumers' concerns which ignited from the "Golden rice controversy" in 2014 when transgenic rice which had been engineered to produce vitamin A was given to schoolchildren without thorough information of the parents. It remains to be seen if the acquisition of Switzerland-based Syngenta by state-owned giant ChemChina in 2018 will change this situation (Table 7).

China accounts for nearly half of global pork production, and fish farmers contribute over $60 \%$ to the global production of fish from aquaculture. Following centuries of traditional breeding, genomic breeding of these and other farm animals is a hotspot of Chinese R\&D. A shortlist of major institutes involved in the genomic breeding of plants and farm animals is provided in Table 8 .

Examples are transgenic Yellow River carps (Luo et al. 2018), engineered at the CAS Institute of Hydrobiology for a triploid expression of the fish's growth hormone leading to a nearly twofold faster growth, and the goat Yangang, created by somatic cloning at Northwest A\&F University (Zhi 2016).

\section{Improving technology}

Compared to industrialized nations, the productivity of Chinese farms is still low. Extensive programs are underway to improve this situation, using China's satellite and IT networks, e.g., for the survey of fields by drones, for driverless agricultural machines, or for enhancing marketing and transportation of agricultural goods. Vertical farming and agricultural IoT are also progressing (Sananbio 2020). Education and urbanization are other policies for absorbing those farmers who have lost their jobs due to technical progress, to reduce rural exodus and to provide better jobs for migrant workers. 
Table 5 Shortlist of enzyme producers in China
Table 6 Measures to facilitate tech transfer from academic R\&D

\begin{tabular}{|c|c|c|}
\hline Company name and location & Type & STN \\
\hline Novozymes China, plants in Tianjin, Shenyang, and Taicang ${ }^{\mathrm{a}}$ & $\mathrm{F}$ & \\
\hline Dupont-Genencor China, Wuxi plant ${ }^{\mathrm{b}}$ & $\mathrm{F}$ & \\
\hline AB Enzymes China, Shanghai ${ }^{\mathrm{c}}$ & $\mathrm{F}$ & \\
\hline DSM Yixing Jiecheng-Engineering ${ }^{d}$, Jiangsu 宜兴杰成 & $\mathrm{P}, \mathrm{F}$ & \\
\hline Sunson Industry Group ${ }^{\mathrm{e}}$, Beijing 北京夏盛 & $\mathrm{P}$ & - \\
\hline Sino Enzymes ${ }^{\mathrm{f}}$, Gansu Province白银赛诺 & $\mathrm{P}$ & - \\
\hline Vland Biotech ${ }^{\mathrm{g}}$, Qingdao 蔚蓝生物 & $\mathrm{P}$ & SHA: 603739 \\
\hline Longda BioProducts ${ }^{\mathrm{h}}$, Shandong 隆大生物 & $\mathrm{P}$ & - \\
\hline Boli Bioproducts, Jiangsu 江苏博立生物制品 & $\mathrm{P}$ & - \\
\hline Yiduoli ${ }^{\mathrm{i}}$ VTR-Biotec, Guandong 溢多利 & $\mathrm{P}$ & SHE: 300381 \\
\hline Xinhuayang ${ }^{\mathrm{j}}$, Hubei 新华扬 & $\mathrm{P}$ & - \\
\hline Challenge Group ${ }^{\mathrm{k}}$, Beijing 挑战集团 & $\mathrm{S}$ & - \\
\hline
\end{tabular}

$P$ private company, $S$ state-owned company, $F$ foreign-owned company, STN stock exchange number

${ }^{\mathrm{a}} \mathrm{https}: / /$ www.novozymes.com/en

${ }^{\mathrm{b}} \mathrm{http}: / /$ biosciences.dupont.com/contact/locations/

${ }^{\mathrm{c}} \mathrm{https}: / /$ www.abenzymes.com/en/global-locations/

${ }^{\mathrm{d}}$ http://www.jch.com.cn/pages/p2.html

${ }^{\mathrm{e}} \mathrm{http}: / /$ www.chinaenzymes.com/index.html

${ }^{\mathrm{f}} \mathrm{http}: / / \mathrm{www} \cdot$ sinoenzymes.com

${ }^{\mathrm{g}} \mathrm{http}: / /$ www.vlandgroup.com/en/about.aspx ?BaseInfoCateId=99\&CateId=99

${ }^{\mathrm{h}} \mathrm{http}: / /$ www.longda-enzyme.com/producten.html

${ }^{\mathrm{i}} \mathrm{http}: / /$ www.yiduoli.com/?lang=en

${ }^{\mathrm{j}} \mathrm{http}: / /$ www.sunhy.cn

${ }^{\mathrm{k}} \mathrm{http}: / /$ www.challenge.com.cn

\begin{tabular}{|c|c|}
\hline Measure & Target group \\
\hline Public researchers may start own company ${ }^{a}$ & Academia \\
\hline Public researchers may keep up to $70 \%$ of profits from the transfer of their patents ${ }^{b}$ & Academia \\
\hline $\begin{array}{l}\text { The technology trading center CTEX-TT offers technology transfer to industry through } 67 \\
\text { local, } 17 \text { professional, and } 3 \text { international channels }{ }^{\mathrm{c}}\end{array}$ & $\begin{array}{l}\text { Academia and } \\
\text { industry }\end{array}$ \\
\hline $\begin{array}{l}20 \text { state venture capital funds in } 2019 \text { held a capital of } 3059 \text { billion } \mathrm{CN} ¥ \text { (equivalent to } 394 \\
\text { billion } €)^{\mathrm{d}} \text {. In addition, there are about } 14,000 \text { private } \mathrm{VC} \text { funds }^{\mathrm{e}}\end{array}$ & $\begin{array}{l}\text { Academia and } \\
\text { industry }\end{array}$ \\
\hline $\begin{array}{l}\text { Both government and industry continuously promote the foundation of cooperative } \\
\text { innovation platforms around emerging technologies }\end{array}$ & Industry \\
\hline Industry can deduct $75 \%$ of $R \& D$ expenditures from tax, manufacturing industry $100 \%$ f & Industry \\
\hline $\begin{array}{l}\text { Central and local governments have established } 169 \text { national and over } 1000 \text { provincial } \\
\text { high-tech zones, which in } 2020 \text { hosted } 225,000 \text { high-tech enterprises }\end{array}$ & Industry \\
\hline
\end{tabular}

${ }^{\mathrm{a}} \mathrm{http} / / /$ politics.people.com.cn/n1/2020/0121/c1001-31557607.html

${ }^{\mathrm{b}}$ http://scitech.people.com.cn/n1/2020/0618/c1007-31751490.html

${ }^{\mathrm{c}}$ https://gyjy.ctex.cn

${ }^{\mathrm{d}} \mathrm{https}: / /$ www.sciping.com/28310.html

${ }^{\mathrm{e}} \mathrm{http} / / / q c c d a t a . q i c h a c h a . c o m / R e p o r t D a t a / P D F / 9155 a e b 68025 b d 7 a 11 a c b 72591 a 3 f f f 5 . p d f$

${ }^{\mathrm{f}} \mathrm{http} / / / \mathrm{www}$.gov.cn/zhengce/2021-03/25/content 5595705.htm

${ }^{\mathrm{g}} \mathrm{http} / / /$ www.gov.cn/xinwen/2020-10/21/content_5553081.htm 


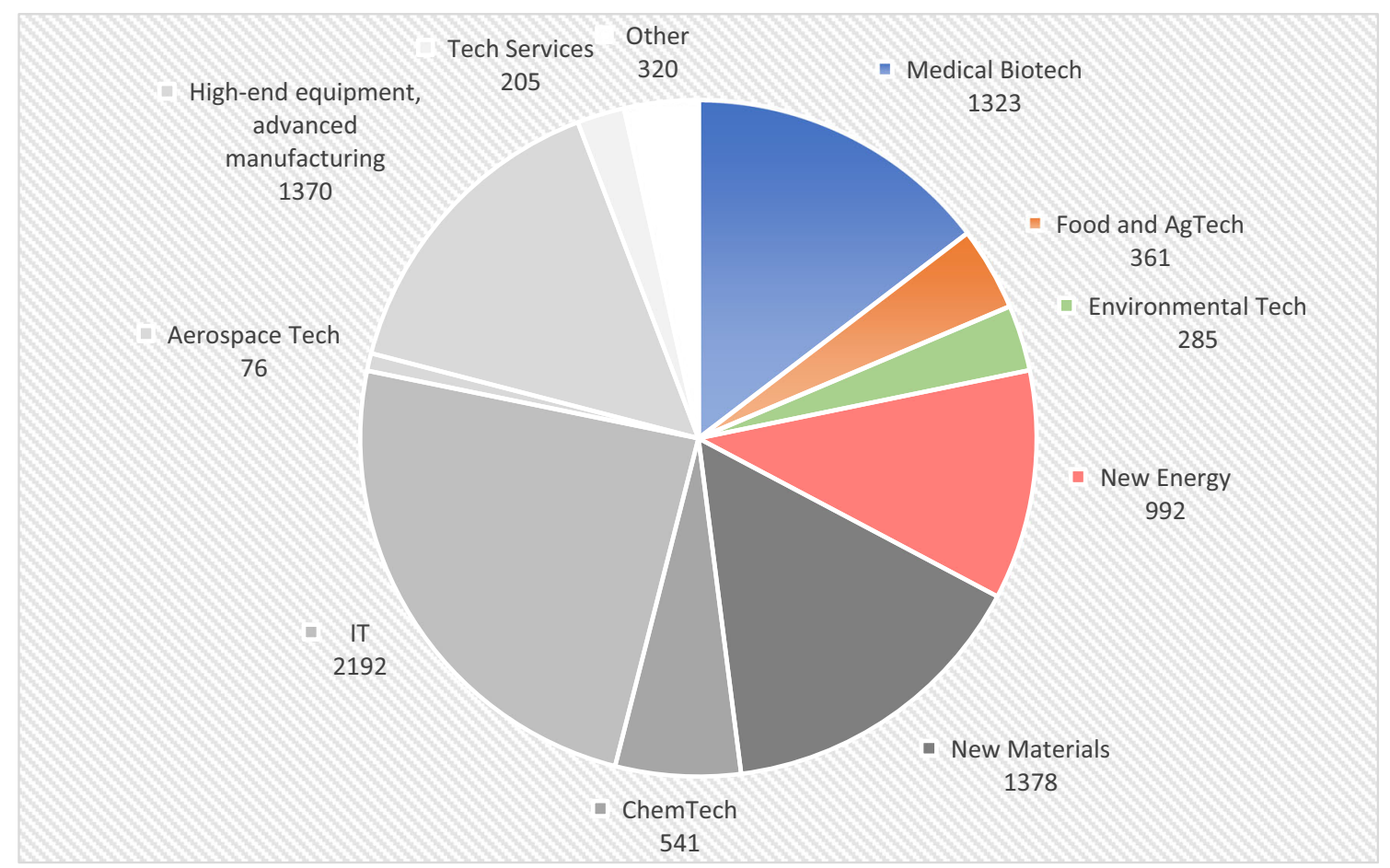

Fig. 3 Snapshot of tech transfer opportunities offered by China Technology Exchange CTEX as of April 11, 2021. Drawn after data from https://gyjy.ctex.cn. Offers arrive from over 170 universities and
R\&D institutions in China and abroad. The annual tech trade volume is claimed to exceed 34 billion CN¥ (equivalent to 4.4 billion $€$ )

\section{Environmental biotechnology}

Similar to other nations, China has suffered from air, water, and soil pollution on its way to rapid industrialization. Over the past decade, the government has initiated more and more rigorous rules to counteract these developments.

\section{Air pollution}

Apart from desert dust and emissions due to construction, car exhausts, industry emissions, household heating, and the burning of straw are the major sources of air pollution and high levels of greenhouse gases. Since 2012, air quality is monitored by a real-time air quality network which in 2019 was based on 1499 stations in 367 cities (AQI-Map 2019). Within the "Air Pollution Prevention and Control Plan" issued in 2015, measures which have some bearing on biotech are:

- The interdiction to burn straw, providing, in theory, 700 million $t$ of this agricultural biomass as a carbon source for fermentation,

- The use of biogas as an energy source, and

- The greening of deserts and planting of trees

In 2018, 58\% of China's energy mix was still based on coal. The combined use of hydropower, nuclear, and solar energy, and wind power is expected to help reduce this figure 
Table 7 Shortlist of Chinese academic groups active in industrial strain and enzyme development

\begin{tabular}{|c|c|c|}
\hline Group & Location & Targets \\
\hline CAS Institute of Industrial Biotechnology ${ }^{a}$ & Tianjin & $\begin{array}{l}\text { Improvement of industrial strains and } \\
\text { enzymes }\end{array}$ \\
\hline $\begin{array}{l}\text { CAS Qingdao Institute of BioEnergy and Bioprocess } \\
\text { Technology }\end{array}$ & Qingdao & $\begin{array}{l}\text { Lignocellulose substrates, algae } \\
\text { biotechnology, biogas technology }\end{array}$ \\
\hline CAS Dalian Institute of Chemical Physics ${ }^{\mathrm{c}}$ & Dalian & Bioenergy-related studies \\
\hline \multirow{2}{*}{$\begin{array}{l}\text { CAS Shanghai Institutes of Biochemistry and Cell } \\
\text { Biology }{ }^{\mathrm{d}} \text {, Institute of Plant Physiology }{ }^{\mathrm{e}} \text {; Shanghai } \\
\text { Institute of Organic Chemistryf; Huzhou Center for } \\
\text { Biosynthetic Innovationg }\end{array}$} & \multirow[t]{2}{*}{ Shanghai } & $\begin{array}{l}\text { SIBCB, SIOC: new industrial strain } \\
\text { development and process } \\
\text { engineering }\end{array}$ \\
\hline & & $\begin{array}{l}\text { Huzhou Center for Biosynthetic } \\
\text { Innovation: tech transfer to industry }\end{array}$ \\
\hline East China University of Science and Technology ${ }^{\mathrm{h}}$ & Shanghai & $\begin{array}{l}\text { Strain development, bioprocess } \\
\text { engineering }\end{array}$ \\
\hline Nanjing Tech University ${ }^{\mathrm{i}}$ & Nanjing & $\begin{array}{l}\text { Strain development, bioprocess } \\
\text { engineering }\end{array}$ \\
\hline Jiangnan University $^{\mathrm{j}}$ & Wuxi & $\begin{array}{l}\text { Strain development, bioprocess } \\
\text { engineering }\end{array}$ \\
\hline Beijing University of Chemical Technology ${ }^{k}$ & Beijing & $\begin{array}{l}\text { Process engineering, synthetic } \\
\text { biology }\end{array}$ \\
\hline
\end{tabular}

${ }^{a}$ http://english.tib.cas.cn

${ }^{\mathrm{b}} \mathrm{http}: / /$ english.qibebt.cas.cn

${ }^{\mathrm{c}} \mathrm{http}: / /$ english.dicp.cas.cn

${ }^{\mathrm{d}} \mathrm{http}: / /$ www.sibcb.ac.cn

${ }^{\mathrm{e}} \mathrm{http}: / /$ www.sippe.ac.cn

${ }^{\mathrm{f}} \mathrm{http}: / /$ english.sioc.cas.cn

${ }^{\mathrm{g}}$ http://www.hzhr.com/Web/Company/20530.html

${ }^{\mathrm{h}}$ https://www2.ecust.edu.cn/_t41/main.htm

${ }^{\mathrm{i}} \mathrm{http} / / /$ www.njtech.edu.cn

${ }^{\mathrm{j}} \mathrm{http} / / /$ english.jiangnan.edu.cn

${ }^{\mathrm{k}} \mathrm{https}: / /$ english.buct.edu.cn to $50 \%$ by 2030 . Though biomass contributes only a few percent to this figure, energy from biomass is already used in over 40 million rural households, $85 \%$ in the form of small household biogas digesters (Felizeter et al. 2017). In addition, gasified straw is seen as a major source of future heating systems in the countryside.

Some $30 \%$ of China's surface are either deserts or covered by sand and stones - a continuing source of dust pollution. With the "Grain for Green" program initiated in 1999, China has paid 124 million farmers in 25 provinces to plant trees on silting ground (Yang 2019), with a target figure of billions of trees until 2050. Genomic breeding of poplar, birch, eucalypt, or larch is actively pursued, e.g., by the Chinese Academy of Agricultural Sciences, but as of 2017, only 542 ha of transgenic poplars was planted (ISAAA 2021).

\section{Water pollution}

A 2016 survey of water samples from some 12,000 official monitoring sites across China revealed that only $35 \%$ of all probes provided water of good quality, and $13 \%$ of contained water is unsuited for any further use (Webber 2017). The 2015 "Water Pollution Prevention and Control Action Plan" therefore demands, among other goals, that by 2020, 95\% of all urban centralized drinking water facilities should produce drinking water of at least class III quality.

Biotech contributes to clean waters mainly through biological sewage treatment plants. Since 1984, the number of such plants has grown to nearly 2300 - trickling filters in smaller communities and activated sludge plants such as the Gaobeidian Water Reclamation Plant in Beijing which has a treatment capacity of 1 million $\mathrm{m}^{3} /$ day. It is claimed, however, that many of these plants do not clean at a desirable ratio, and the sewer systems leading to these plants may still be incomplete (QU et al. 2019).

Algal blooms in China's lakes, largely caused by emissions from agriculture, and marine pollution along China's 18,000$\mathrm{km}$ coastline, caused by seaweed farming and pollution, lead to frequent "green tides" in places lake Qingdao (Wang et al. 2015). 
Table 8 Shortlist of academic institutes involved in research on molecular breeding in China

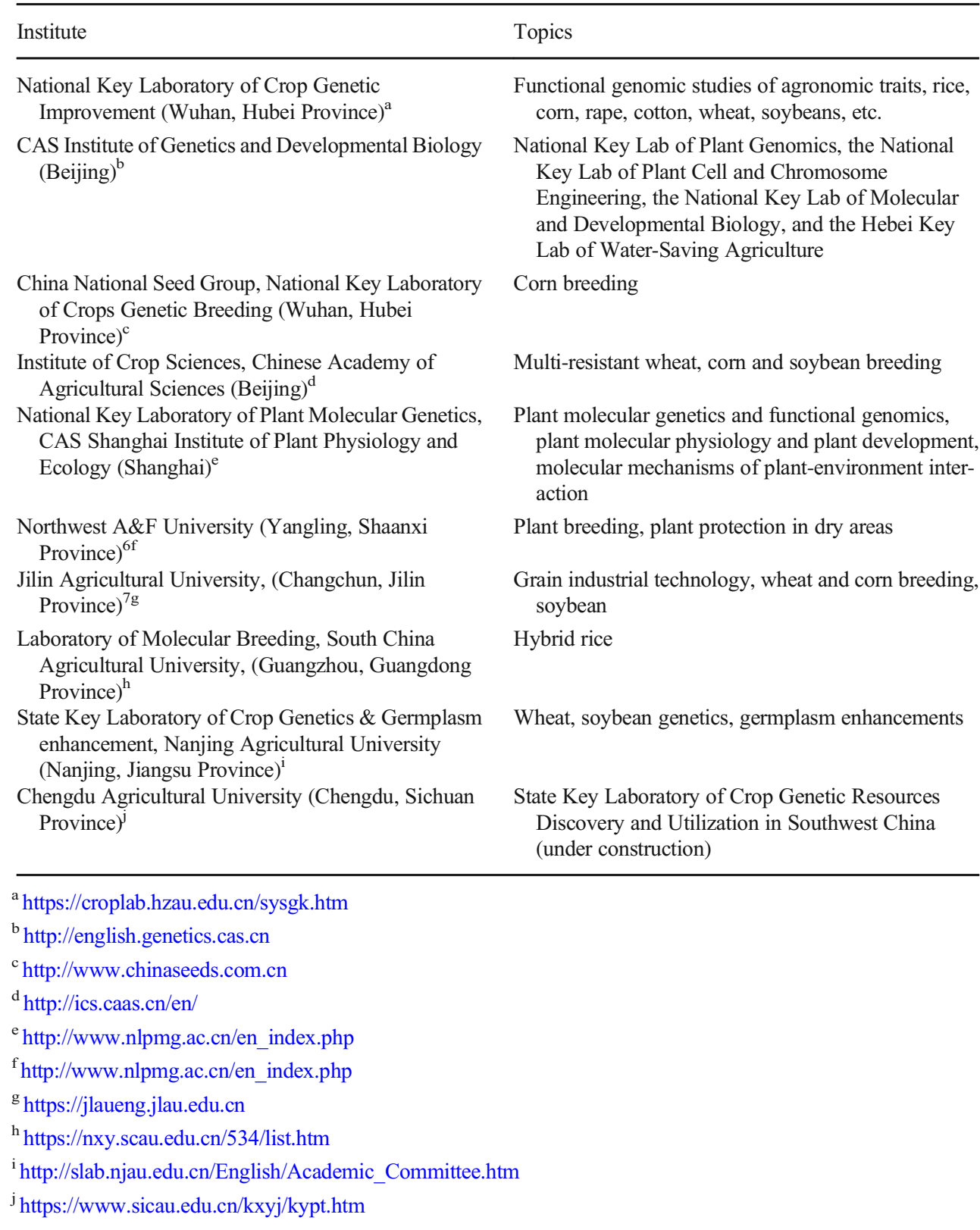

\section{Soil pollution}

Due to rapid industrialization, coal firing, and increase of traffic, China's urban soils are polluted in many places. Soil remediation is under study but presently not yet carried out at a larger scale (Zhang and Chen 2017).

\section{Greenhouse gases}

China, with $19 \%$ of the global population, accounts for $27 \%$ of global greenhouse gas emissions. Having signed the 2015 Paris Agreement on Climate Change, China has vowed to peak $\mathrm{CO}_{2}$ emissions by 2030 and become carbon-neutral by
2060 at the latest (Zheng et al. 2020). Pertinent measures such as investments in non-fossil energies and planting of trees are high on the political agenda, more and more stringent control of emissions from space, and new research centers, e.g., the Shandong Energy Institute (He 2020).

\section{Biodiversity}

Extending over many climate zones, China has a rich biodiversity. In 1994, the country joined the UN Convention on Biological Diversity (Cartagena Protocol) and started to implement rules and regulations for eco-environmental protection. In 2019, the CAS published an online catalogue of 
Table 9 Fermented food and drink in China

\begin{tabular}{|c|c|c|}
\hline Type of food or drink & $\begin{array}{l}\text { Estimated amount } \\
\text { produced }\end{array}$ & Remarks \\
\hline $\begin{array}{l}\text { Soybean paste (douchi and } \\
\text { jiang) }\end{array}$ & $915,000 \mathrm{t}(2019)$ & 34 companies \\
\hline Soy sauce & 10 million $\mathrm{t}(2018)$ & Mixed cultures of $A$. oryzae and lactobacilli \\
\hline Vinegar & 5 million (2018) & $\begin{array}{l}>6000 \text { companies, from grains by mixed culture } \\
\text { of molds }\end{array}$ \\
\hline Yoghurt & 9.6 million $\mathrm{t}(2018)$ & $\sim 50$ companies, top 3 share $91 \%$ of the market \\
\hline $\begin{array}{l}\text { White liquor }(40-55 \% \\
\text { alcohol), baijiu }\end{array}$ & 7.9 billion L (2019) & $\begin{array}{l}\text { Sales volume for companies with over } 20 \text { Mio. } \\
\text { CN¥ turnover }\end{array}$ \\
\hline $\begin{array}{l}\text { Rice wine (14 - 17\% alcohol), } \\
\text { huangjiu }\end{array}$ & 3.5 billion L(2019) & \\
\hline Beer & 38 billion L (2019) & 27-28 L/capita, import 730 million L \\
\hline Grapewine & 450 million L $(2019)^{13}$ & $\begin{array}{l}\text { China is among the top } 10 \text { global producers and } \\
\text { importers }\end{array}$ \\
\hline
\end{tabular}

Compounded data from various statistical resources and market surveys
China's biological resources, containing 7 million records (Chen 2019). Since 2017, 11 National Parks covering some $200,000 \mathrm{~km}^{2}$ are under mandatory and rigorous protection.

\section{Expectations for the 14th five-year period "145" relating to biotech}

Based on the great advances on S\&T including biotech-related R\&D in China during the "135" period, all evidence points to a continuation or even acceleration in most fields which were discussed in this article.

- Government expenditure on R\&D will rise beyond the present $2.4 \%$ of GDP, industrial R\&D will be even stronger supported by tax exemptions, and more money will be spent on fundamental R\&D in academia,

- R\&D infrastructure will be further expanded, and we will see more national research centers like the CAS National Center for Protein Science which opened in 2015 in Shanghai (http://www.ncpss.org),

- Medical care will be further improved, taking advantage of big data, Internet-based services, and financial stimuli for not only innovative drugs and equipment, but also stringent cost control of generic drugs and instrumentation (GTAI 2021),

- Genomic medicine, IT-based diagnostic services, and cell technology will be a focus of not only the next developments, but also the stimulation of TCM,

- Brain-related R\&D will be strongly stimulated, based on China's unique resource of macaque and rhesus monkeys,

- Research on agricultural biotech, targeting crops, trees, husbandry, fish, and algae, will be further expanded; however, translation to food products may still be hampered in view of consumers' concerns,

- IT-Based cultivation, harvesting, processing, and marketing of agricultural goods will strongly increase,

- Industrial biotech will see a continuing trend towards less wasteful processes, and support for programs related to a cyclic economy or bioeconomy will increase, taking advantage on China's huge resources of waste products such as straw or food waste,

- Measures to ensure cleaner air, water, marine environments, and, eventually, soil will remain high-priority targets, leading to the construction of more sewers, sewage plants, and biogas reactors in the countryside,

- Finally, China will continue to export its technologies to the less industrialized countries, for instance through the belt-and-road program (Belt and Road Initiative (BRI)), and by these means will make an important contribution to the technical empowerment of hitherto less developed nations.

Author contribution RDS searched pertinent information in PubMed as well as other Western databases and wrote the article; XX contributed through the analysis of Chinese databases and blogs. Both the authors read and approved the manuscript.

Funding X. Xiong acknowledges partial support of this study by grant "6D-BioBone" (ProjectNr.: FKZ 13GW0400C), German Federal Ministry of Education and Research (BMBF).

Declarations This article does not contain any studies with human participants or animals performed by any of the authors.

Conflict of interest The authors declare no competing interests. 


\section{References}

AQI-Visual Map (2019) Air pollution in China: real-time air quality index visual map. https://aqicn.org/map/china/. Accessed 6 February 2021

BGI (2017) NIFT: non-invasive prenatal testing. https://www.bgi.com/ global/wp-content/uploads/sites/3/2017/04/NIFTY-Brochure-ENG0720.pdf. Accessed 6 February 2021

BGI (2018) BGI publishes largest ever genomic study of Chinese population discoveries in more than 140,000 genomes throughout China. https:/www.bgi.com/us/wp-content/uploads/sites/2/2018/10/BGIPublishes-140K-Genomes-Study-of-Chinese-Population-pressrelease-final-10.4.pdf. Accessed 6 February 2021

Cao MM, Li H, Sun DQ, Chen WQ (2020) Cancer burden of major cancers in China: a need for sustainable actions. Cancer Communications 40(5):205-210. https://doi.org/10.1002/cac2. 12025

CAS (2020) CAS Institutes. http://english.cas.cn/cl/. Accessed 6 February 2021

CER- China Economic Report (2020) China Development Report 2020: aging to peak in 2050. http://www.china-cer.com.cn/guwen/ 202006276117.html. Accessed 6 February 2021

Chang L (2019) Milk consumption continues to grow rigidly. http:// www.gov.cn/xinwen/2019-05/23/content_5393936.htm. Accessed 6 February 2021

Chen N (2019) China releases catalogue of biological resources. CAS news. http://english.cas.cn/head/201912/t20191211_227536.shtml. Accessed 6 February 2021

Chen S (2020) Ministry of Transportation: China's total railroad mileage is expected to reach $146,000 \mathrm{~km}$ by the end of the year. http://www. chinanews.com/gn/2020/05-19/9188924.shtml. Accessed 6 February 2021

CHYXX (2019)-China Industry Information Network, output value of China's feed enzyme industry in 2018. https://www.chyxx.com/ industry/201912/817174.html. Accessed 6 February 2021

CNBS-Chinese National Bureau of Statistics (2020a) 2019 National Science and Technology Investment Statistics Bulletin. http:// www.stats.gov.cn/tjsj/zxfb/202008/t20200827 1786198.html. Accessed 6 February 2021

CNBS-Chinese National Bureau of Statistics (2020b)-3 Statistic data: GDP of 2019. https://data.stats.gov.cn/search.htm?s=GDP. Accessed 6 February 2021

Cyranoski D (2018) Beijing launches pioneering brain-science centreChina's much-anticipated brain initiative finally starts to take shapes. Nature 556:157-158. https://doi.org/10.1038/d41586-01804122-3

Du Z, Ma L, Qu H, Chen W, Zhang B, Lu X, Zhai W, Sheng X, Sun Y, Li W, Lei M, Qi Q, Yuan N, Shi S, Zeng J, Wang J, Yang Y, Liu Q, Hong Y, Dong L, Zhang Z, Zou D, Wang Y, Song S, Liu F, Fang X, Chen H, Liu X, Xiao J, Zeng C (2019) Whole genome analyses of Chinese population and de novo assembly of a northern Han genome. Genomics Proteomics Bioinformatics 17(3):229-247. https:// doi.org/10.1016/j.gpb.2019.07.002

Famous Scientists (2018) "Youyou Tu." www.famousscientists.org/ youyou-tu/. Accessed 6 February 2021

Felizeter B, Schalit V, Peng QZ, Chen KY (2017) Chinaeffizienzsteigerung im Biogassektor in Nordchina. German industry \& Commerce greater China. https://www.oav.de/fileadmin/user upload/2_Termine/China_VR/cn_170707_ZMA_Biogas_2017 FINAL.pdf. Accessed 6 February 2021

GTAI (2021) We are following up on these developments since 2019 through our monthly Pharma and MedTech newsletter (in German language), https://www.gtai.de/gtai-de/trade/service/newsletter/ eigw-profil
Guo XL (2021) Chinese team to turn $6.7 \mathrm{mln}$ hectares of saline-alkali land into paddies. http://en.people.cn/n3/2021/0116/c90000-9810221. html. Accessed 6 February 2021

Gurry F (2020) China becomes top filer of international patents in 2019 amid robust growth for WIPO's IP services, treaties and finances. https://www.wipo.int/pressroom/en/articles/2020/article_0005. html. Accessed 6 February 2021

He YT (2020) Shandong energy research institute officially starts construction in Qingdao. Seetao news. https://www.seetao.com/details/ 47110/en.html. Accessed 6 February 2021

$\mathrm{Hu}$ L, Zhao B, Wang SL (2018) Stem cell therapy advances in China Human Gene Therapy 29(2):188-196. https://doi.org/10.1089/hum. 2017.224

ISAAA (2021) ISAAA SEAsia Center, About us. https://www.isaaa.org/ inbrief/regionalcenters/seasiacenter/default.asp. Accessed 6 February 2021

Jin YZ (2021) Only 200 PLA-related companies. https://www.yicai.com/ news/100902504.html. Accessed 6 February 2021

Jin GY, Zhu Y, Xu Y (2017) Mystery behind Chinese liquor fermentation. Trends in Food Science \& Technology 63:18-28. https://doi. org/10.1016/j.tifs.2017.02.016

Lanza Tech (2018) The first industrial device in the world high efficiency cleaning. http://www.bjsgltne.com/odds. Accessed 6 February 2021

Liu YZ (2020) The national motor vehicle fleet reached 365 million units. http://www.xinhuanet.com/auto/2020-10/22/c_1126641255.htm. Accessed 6 February 2021

Luo L, Huang R, Zhang AD, Yang C, Chen LM, Zhu DH, Li YM, He LB, Liao LJ, Zhu ZY, Wang YP (2018) Selection of growth-related genes and dominant genotypes in transgenic Yellow River carp Cyprinus carpio L. Funct Integr Genomics 18:425-437. https:// doi.org/10.1007/s10142-018-0597-9

MOE- Ministry of Education of China (2020)-2 2019 Statistics on students studying abroad. http://www.moe.gov.cn/jyb_xwfb/gzdt gzdt/s5987/202012/t20201214_505447.html. Accessed 6 February 2021

MOE-Ministry of Education of China (2020)-1 2019 National Education Development Statistics Bulletin. http://www.moe.gov.cn/jyb sjzl/ sjzl_fztjgb/202005/t20200520_456751.html. Accessed 6 February 2021

MOST- Chinese Ministry of Science and Technology (2019) 2019 National High-tech Zone Innovation Capacity Evaluation Report. http://www.most.gov.cn/cxdc/cxdcpjbg/202002/ P020200218407424538366.pdf. Accessed 6 February 2021

Mu XF (2020) Analysis of China's milk market size and development prospects in 2020. https:/www.qianzhan.com/analyst/detail/220/ 200824-529deefb.html. Accessed 6 February 2021

Nature Index 2020 (2020) The ten leading countries in natural-sciences research. https://www.nature.com/articles/d41586-020-01231-w. Accessed 6 February 2021

NRCMM-National Resource Center for Mutant Mice of China (2020) National Resource Center for Mutant Mice of China-introduction. https://www.nju.edu.cn/EN/wationalwwesourcewwenterwfor wwutantwwicewofwwhina/list.htm. Accessed 6 February 2021

People's Daily (2020) Chinese new COVID-19 vaccine approved for marketing. https://wap.peopleapp.com/article/rmh17846307/ rmh17846307. Accessed 6 February 2021

Qu J, Wang H, Wang K, Yu G, Ke B, Yu HQ, Ren HQ, Zheng XC, Li J, Li WW, Gao S, Gong H (2019) Municipal wastewater treatment in China: development history and future perspectives. Front Environ Sci Eng (13):88. https://doi.org/10.1007/s11783-019-1172-x

SananBio (2020) Sananbio grow systems. https://sananbio.com. Accessed 6 February 2021

Shi L, Luo X, Jiang J, Chen YC, Liu CR, Hu T, Li M, Lin Q, Li YJ, Huang J, Wang H, Niu YY, Shi YD, Styner M, Wang JH, Lu Y, Sun XJ, Yu HL, Ji WZ, Su B (2019) Transgenic rhesus monkeys carrying the human $\mathrm{MCPH1}$ gene copies show human-like neoteny of 
brain development. Natl Sci Rev 6(3):480-493. https://doi.org/10. 1093/nsr/nwz043

Shi BY, Liu ZJ, Yu T (2020) Development of the prgan donation and transplantation system in China. Chin Med J (Engl.) 133(7):760 765. https://doi.org/10.1097/CM9.0000000000000779

Sinogene (2020) Sinogene pet cloning service. https://www.sinogene. org. Accessed 6 February 2021

Statista (2019) Estimated number of people with diabetes mellitus in China in 2019, by age group. https://www.statista.com/statistics/ 1118008/china-diabetic-population-by-age-group/. Accessed 6 February 2021

Sun S, Yu K, Xie Z, Pan X (2020) China empowers Internet hospital to fight against COVID-19. J Infect. 81(1):e67-e68. https://doi.org/10. 1016/j.jinf.2020.03.061

Wang ZL, Xiao J, Fan SL, Li Y, Liu XQ, Liu DY (2015) Who made the world's largest green tide in China? An integrated study on the initiation and early development of the green tide in Yellow Sea. Limmol Acceanogr (60):1105-1117. https://doi.org/10.1002/lno. 10083

Wang Y, Lei TT, Wei L, Du SY, Girani L, Deng SP (2019) Xenotransplantation in China: present status. Xenotransplantation 26(1):e12490. https://doi.org/10.1111/xen. 12490

Webber M (2017) Tackling China's water pollution. Global Water Forum. https://globalwaterforum.org/2017/10/09/tackling-chinaswater-pollution/. Accessed 6 February 2021

Wen W (2018) Chinese people drink 33 liters of beer a year per capita. https://www.zhitongcaijing.com/content/detail/133098.html. Accessed 6 February 2021

Wen JH (2020) The 169 national high-tech zones accounted for $12.3 \%$ of the national total GDP in 2019. http://www.xinhuanet.com/fortune/ 2020-07/23/c_1126277983.htm. Accessed 6 February 2021
WHO (2020) World Health Statistics 2020. https://apps.who.int/iris/ bitstream/handle/10665/332070/9789240005105-eng.pdf. Accessed 6 February 2021

Wu S (2018) 160 The pig model project of China. J Anim Sci 96(Suppl 3):291-292. https://doi.org/10.1093/jas/sky404.640

Yang S (2019) Extensive reforestation in China makes earth greener. Global times. https://www.globaltimes.cn/content/1139006.shtml. Accessed 6 February 2021

Yang WC, Xu H (2016) Industrial fermentation of vitamin. In: Vandamme EJ, Revuelta JL (eds) Industrial biotechnology of vitamins, biopigments and antioxidants. Wiley VCH, pp 161-193

Yi N (2021) China has completed 22,767,000 doses of the vaccination against COVID-19. https://www.chinanews.com/gn/2021/01-27/ 9397742.shtml. Accessed 6 February 2021

Zhang YS (2019) Chemical Industry 2019 Medium term investment strategy: coal-to-ethanol may become the next investment hotspot in the chemical industry. http://pdf.dfcfw.com/pdf/H3 AP201906181335684205 1.pdf. Accessed 6 February 2021

Zhang P, Chen YG (2017) Polycyclic aromatic hydrocarbons contamination in surface soil of China: a review. Science of the total Environment (605-606):1011-1020. https://doi.org/10.1016/j. scitotenv.2017.06.247

Zheng XQ, Lu YL, Yuan JJ, Baninla Y, Zhang S, Stenseth N, Hessen D, Tian HQ, Obersteiner M, Chen DL (2020) Driver of change in China's energy-related $\mathrm{CO}_{2}$ emissions. PNAS 1(117):29-36. https://doi.org/10.1073/pnas.1908513117

Zhi YP (2016) Cloned goat Yangyang died at age of 16. https://en. nwsuaf.edu.cn/news/64323.htm. Accessed 6 February 2021

Publisher's note Springer Nature remains neutral with regard to jurisdictional claims in published maps and institutional affiliations. 